\title{
Leaf Blade Stomatal Characterizations and Evapotranspiration Rates of 12 Cool-season Perennial Grasses
}

\author{
R.L. Green, J.B. Beard, and D.M. Casnoff \\ Department of Soil and Crop Sciences, Texas A\&M University, College \\ Station, TX 77843 \\ Additional index words. abaxial and adaxial leaf surface, Agrostis, Festuca, Loliurn, \\ Poa, stomatal arrangement
}

\begin{abstract}
The objectives of this investigation were to determine the stomatal frequencies of 12 perennial cool-season turfgrasses, encompassing nine species, and their associated evapotranspiration (ET) rates under nonlimiting soil moisture and controlled environmental conditions. Significant differences in stomatal density were found among the 12 cool-season turfgrasses on both the abaxial $(P>F=0.0008)$ and adaxial $(P>$ $F=0.0009)$ leaf surfaces. Significant differences $(P>F=0.0007)$ in ET rates also were found among the 12 cool-season turfgrasses. The Kentucky bluegrass (Pea pratensis L.) cultivars exhibited the highest ET rates, while the fine-leafed fescues (Festuca rubra and longifolia L.) exhibited the lowest rates, except for 'Big Horn' sheep fescue (Festuca ovina L.), which exhibited an intermediate ET rate. No significant correlation was found between ET rate and either adaxial or abaxial stomatal density. It was concluded that, under nonlimiting soil moisture conditions, stomatal density was not reliably associated with ET rate.
\end{abstract}

A major concern in the development of minimal maintenance turfs is the breeding of grasses with increased drought resistance and/ or reduced evapotranspiration (ET) rates while maintaining acceptable turf quality under irrigated conditions. Although stomata comprise only $\approx 1 \%$ of the total leaf blade surface area, they serve as key sites for transpiration and thus are of interest in reducing water loss.

Johns et al. (1983), studying resistances to ET from St. Augustinegrass [Stenotaphrum secundatum (Walt.) Kuntze], showed that, when adequately watered, $20 \%$ to $30 \%$ of actual ET was controlled by resistance of the leaf epidermis and stomata, but that ET was influenced to a much greater extent by aerodynamic and canopy resistances. Casnoff et al. (1989), studying leaf blade stomatal arrangement and density of 10 warmseason perennial turfgrasses and their association to ET rates, found significant differences among turfgrasses for ET rate and stomatal density. They noted a significant negative correlation between ET rate and abaxial stomatal density. Shearman (1986), working with a collection of 20 well-watered Kentucky bluegrass (Pea pratensis) cultivars, found significant differences among them for ET rate, shoot density, verdure, and adaxial stomatal density. Only verdure was significantly correlated to cultivar ET rates.

Received for publication 8 Aug. 1988. Texas Agr. Expt. Sta., JournaI Article no. TA 23797. A major portion of this investigation has been made possible by a grant from the U.S. Golf Assn. Green Section. The cost of publishing this paper was defrayed in part by the payment of page charges. Under postal regulations, this paper therefore must be hereby marked advertisement solely to indicate this fact.
Dobrenz et al. (1969) reported no correlation between water-use efficiency and either abaxial or adaxial stomatal density for blue panicgrass (Panicum antidotale Retz.).

The objectives of this study were to 1) characterize the stomatal densities of 12 perennial cool-season turfgrasses encompassing nine species and 2) assess their associated ET rates under nonlimiting soil moisture conditions and uniform cultural practices in a controlled-environment simulation chamber.

The 12 cool-season turfgrasses characterized in this study were creeping annual bluegrass [Poa annua var. reptans (Hausskn.) Timm], chewings fescue (Festuca rubra ssp. commutata Gaud. 'Jamestown'), creeping bentgrass [Agrostis stolonzfera L. var. palustris (Huds.) Farw. 'Penncross'], hard fescue ( $F$. longifolia Thuill. 'Waldina'), Kentucky bluegrass ('Bensun', 'Majestic', and 'Merion'), perennial ryegrass (Lolium perenne L. 'Manhattan II'), rough bluegrass $(P$. trivialis L. 'Sabre'), sheep fescue ( $F$. ovina ssp. vulgaris 'Big Horn'), and tall fescue (F. arundinacea Schreb. 'Kentucky 31' and 'Rebel'). Three replicates of each turfgrass were seeded at recommended rates (Beard, 1973) and grown in a glasshouse in black plastic containers (minilysimeters; 210 $\mathrm{mm}$ in diameter $\mathrm{x} 210 \mathrm{~mm}$ deep) filled with fritted clay. Fritted clay was chosen as the growth medium based on the work of Van Bavel et al. (1978). The glasshouse was controlled for a minimum and maximum of 21 and 32C. Turfs were mowed weekly with a reel mower at a 50-mm cutting height, clippings were removed. The turf was watered daily to prevent visual wilt and fertilized biweekly with a nutrient solution $(23.0 \mathrm{~N}-8.4 \mathrm{P}$ $14.1 \mathrm{~K}$ plus micronutrients) at $2.4 \mathrm{~g} \mathrm{~N} / \mathrm{m}^{2}$ per month; hard fescue received no $\mathrm{N}$ fertilizer because of our past experience of producing poor turfgrass quality when fertilized with $\mathrm{N}$ at the amount specified for this study. This zero $\mathrm{N}$ application may have affected measurements, but turfs of hard fescue were representative of field-grown turf. After 5 months establishment, all turfs were well rooted (without restriction) and had canopies representative of field-grown turfs. No disease or insect injury was visually evident.

One week before stomatal and ET rate characterizations, the turfs were transferred from the glasshouse to a controlled-environment growth chamber and preconditioned. Days and nights were at $22 \mathrm{C}$, photoperiod was $14 \mathrm{hr}$, and photosynthetic photon flux (PPF) was $500 \mu \mathrm{mol} \cdot \mathrm{s}^{-1} \cdot \mathrm{m}^{-2}(\approx \approx 6 \%$ of full sunlight). Following acclimation, turfs were mowed, immediately sampled for stomatal characterizations, and then -placed in the controlled-environment simulation chamber for ET rate determinations. Four of the youngest fully expanded leaf blades were excised from each turfgrass canopy. Two abaxial and two adaxial leaf blade impressions were made using a procedure described by Rice et al. (1979). Two stomatal density counts, each of $0.25 \mathrm{~mm}^{2}$, were made from the midportion of each leaf blade impression at $\times 200$. Counts were converted to a squaremillimeter basis.

Immediately following excision of leaf blades, the turfs were placed in a controlledenvironment simulation chamber, as described by Johns et al. (1983), to assess ET rates. The chamber was modified to simultaneously accommodate four minilysimeters. To induce a high evaporative demand, temperature was $22 \mathrm{C}$, dewpoint was $12 \mathrm{C}(\approx 53 \%$ $\mathrm{RH}$ ), photoperiod was $14 \mathrm{hr}$, PPF was 1080 $\mu \mathrm{mol} \cdot \mathrm{s}^{-1} \cdot \mathrm{m}^{-2}$ ( $\varsubsetneqq 3 \%$ full sunlight $)$, and average air velocity was $0.5 \mathrm{~m} \cdot \mathrm{s}^{-1}$, measured at $0.15 \mathrm{~m}$ above the canopy. ET rate for 24 hr was determined three times for each minilysimeter by the water balance method (Kim and Beard, 1988). Analysis of variance for all dependent variables was a randomized complete-block design; each complete block was analyzed one at a time, four minilysimeters at a time. Blocks were not significantly different for ET rate, indicating that the simulation chamber maintained fairly constant conditions during the study. Correlations of genotype means were made between dependent variables.

Significant differences in stomatal density were found among the 12 cool-season turfgrasses for both the abaxial $(P>\mathrm{F}=0.0008)$ and adaxial $(P>\mathrm{F}=0.0009)$ leaf surfaces (Table 1). Stomatal density can be affected by both environmental and cultural conditions during leaf development (Shearman and Beard, 1973). The most important aspect reported herein involves the relative interspecies stomatal differences and associated ET rate under defined controlled-environment conditions, rather than absolute values, as related to various growing conditions. Defining standard environmental conditions was necessary when producing baseline data.

Turfgrasses with the highest adaxial stomatal density included 'Waldina' hard fes- 
Table 1. Comparative stomatal densities and ET rates for 12 cool-season turfgrasses.

\begin{tabular}{|c|c|c|c|c|}
\hline \multirow[b]{2}{*}{ Turfgrass } & \multirow[b]{2}{*}{ Cultivar } & \multicolumn{2}{|c|}{ Stomata $\left(\text { no. } / \mathrm{mm}^{2}\right)^{z}$} & \multirow{2}{*}{$\begin{array}{c}\text { ET rate } \\
\left(\mathrm{mm} \cdot \text { day }^{-1}\right) \\
\end{array}$} \\
\hline & & Adaxial & Abaxial & \\
\hline Hard fescue & Waldina & $203 a^{x}$ & $0 \mathrm{~d}$ & $7.4 \mathrm{e}$ \\
\hline Creeping bentgrass & Penncross & $176 a b$ & $100 \mathrm{a}$ & 10.1 abcd \\
\hline Sheep fescue & Big Horn & $147 a b c$ & $0 \mathrm{~d}$ & $9.3 \mathrm{cde}$ \\
\hline Chewings fescue & Jamestown & $142 \mathrm{abcd}$ & $0 \mathrm{~d}$ & $7.7 \mathrm{de}$ \\
\hline Creeping annual bluegrass & -- & 135 bcde & $71 \mathrm{ab}$ & 9.8 bcde \\
\hline Kentucky bluegrass & Bensun & 125 bcdef & $41 \mathrm{bcd}$ & $12.4 \mathrm{a}$ \\
\hline Perennial ryegrass & Manhattan II & 125 bcdef & $17 \mathrm{~cd}$ & 9.1 cde \\
\hline Tall fescue & Rebel & 88 cdef & $46 \mathrm{bcd}$ & $11.4 \mathrm{abc}$ \\
\hline Rough bluegrass: & Sabre & $87 \mathrm{cdef}$ & $0 \mathrm{~d}$ & $8.4 \mathrm{de}$ \\
\hline Kentucky bluegrass & Majestic & 79 def & $37 \mathrm{bcd}$ & $11.9 \mathrm{ab}$ \\
\hline Kentucky bluegrass & Merion & $73 \mathrm{ef}$ & $24 \mathrm{bcd}$ & $12.4 \mathrm{a}$ \\
\hline Tall fescue & $\mathrm{K}-31$ & $68 \mathrm{f}$ & 55 bc & 9.9 abcde \\
\hline
\end{tabular}

${ }^{2}$ Stomatal density based on two counts at $\times 200$ (each measured area was $0.25 \mathrm{~mm}^{2}$ ) from each of two leaf blade impressions per minilysimeter.

'ET rate based on minilysimeter measurements (three sequential measurements from each minilysimeter) made in $24 \mathrm{hr}$ under nonlimiting soil moisture conditions in a controlled-environment simulation chamber having a photoperiod of $14 \mathrm{hr}$, PPF of $1080 \mu \mathrm{mol} \cdot \mathrm{s}^{-1} \cdot \mathrm{m}^{-2}$, wind speed of $0.5 \mathrm{~m} \cdot \mathrm{s}^{-1}$ measured $0.15 \mathrm{~m}$ above turf canopy, and air temperature and dewpoint maintained at 22 and $12 \mathrm{C}$, respectively. 'The mean of three replications. Mean separation in columns by Duncan's multiple range test, $P=$ 0.05 .

cue and 'Penncross' creeping bentgrass; those ranking lowest included 'Merion' Kentucky bluegrass and 'Kentucky 31' tall fescue (Table 1).

Turfgrasses ranking highest in abaxial stomatal density included 'Penncross' creeping bentgrass and creeping annual bluegrass. 'Sabre' rough bluegrass, 'Jamestown' chewings fescue, 'Big Horn' sheep fescue, and 'Waldina' hard fescue had no stomata in their abaxial leaf surfaces. Perennial ryegrass had stomata only adjacent to and on both sides of the midrib, while all other species had stomata over the entire abaxial surface, except for the fine-leafed fescues and rough bluegrass, which had no stomata.

Stomatal densities were greater on the adaxial than on the abaxial surface for most of the turfgrasses. Previous work with 'Penncross' creeping bentgrass (Shearman and Beard, 1972) and Kentucky bluegrass cultivars (Dernoeden and Butler, 1979) showed the same relationship in stomatal density between the two leaf blade surfaces. There was no significant correlation between. the abaxial and adaxial stomatal densities for the 12 cool-season turfgrasses; unlike the significant positive correlation $(r=0.87)$ reported by Casnoff et al. (1989) for 10 major warmseason turfgrasses.

Significant differences $(P>\mathrm{F}=0.0007)$ for ET rate were found among the 12 coolseason turfgrasses, ranging from 7.4 $\mathrm{mm} \cdot$ day $^{-1}$ for 'Waldina' hard fescue to 12.4 $\mathrm{mm} \cdot \mathrm{day}^{-1}$ for 'Merion' Kentucky bluegrass, when grown under nonlimiting moisture conditions (Table 1). The highest ET rates were exhibited by the Kentucky bluegrasses and the lowest by the fine-leafed fescues, except for 'Big Horn' sheep fescue. The ET rates were higher than those reported or expected for field conditions in the cool climatic region (day and night temperatures did not fluctuate in this study), although the relative rankings of species are similar (Aronson et al., 1987). However, ET rates were comparable to those reported in warm climatic regions (Beard, 1985). Significant in terspecies variations in ET rates also have been reported among the major warm-season turfgpasses (Casnoff et al., 1989; Kim and Beard, 1988) and at the intraspecies level among a collection of 20 Kentucky bluegrass cultivars (Shearman, 1986) and among a collection of six tall fescue cultivars (Kopec et al., 1988).

In this study, no significant correlation was found between ET rate and either adaxial or abaxial stomatal density. Casnoff et al. (1989) reported a significant negative correlation $(r$ $=0.43$ ) between ET rate and the abaxial stomatal density and no correlation between ET rate and the adaxial stomatal density for 10 warm-season turfgrasses. Shearman (1986) reported that ET rate was not correlated to adaxial stomatal density but was correlated to verdure among 20 Kentucky bluegrass cultivars.

This research and other work involving turfgrasses (Aronson et al., 1987; Casnoff et al., 1989; Johns et al., 1983; Kim and Beard, 1988; Shearman, 1986) indicates that considerable inter- and intraspecies variation exists in ET rates. Also, this study shows that, under nonlimiting soil moisture conditions, the stomatal density is not reliably associated with the ET rate for 12 cool-season perennial grasses. Breeding programs designed to develop water-conserving turfgrasses, especially for irrigated conditions, should place priority on plant characteristics that increase canopy resistance and decrease leaf area, rather than attempting to manipulate leaf stomatal density, which has little effect on ET rate under nonlimiting soil moisture conditions.

\section{Literature Cited}

Aronson, L. J., A.J. Gold, R.J. Hull, and J.L. Cisar. 1987. Evapotranspiration of cool-season turfgrasses in the humid Northeast. Agron. J. 79:901-905.

Beard, J.B. 1973. Turfgrass: Science and culture. Prentice-Hall, Englewood Cliffs, N.J.

Beard, J.B. 1985. An assessment of water use by turfgrass, p. 47-60. In: V. A. Gibeault and S.T. Cockerham (cd.). Turfgrass water conservation, Univ. of California, Div. of Agr. and Natural Resources Publ. 21405.

Casnoff, D. M., R.L. Green, and J.B. Beard. 1989. Leaf blade stomatal densities of ten warm-season perennial grasses and their evapotranspiration rates, p. 129-131. In: H. Takatoh (ed.). Proc. 6th Intl. Turfgrass Res. Conf., Tokyo, July 1989. Jpn. Soc. Turfgrass Sci.

Dernoeden, P.H. and J.D. Butler. 1979. Relation of various plant characters to drought resistance of Kentucky bluegrass. HortScience 14:511-512.

Dobrenz, A. K., L.N. Wright, A.B. Humphrey, M.A. Massengale, and W.R. Kneebone. 1969. Stomate density and its relationship to wateruse efficiency of blue panicgrass (Panicum antidotale Retz.) Crop Sci. 9:354-357.

Johns, D., J.B. Beard, and C.H.M. van Bavel. 1983. Resistances to evapotranspiration from a St. Augustinegrass turf canopy. Agron. J. 75:419-422.

Kim, K.S. and J.B. Beard. 1988. Comparative turfgrass evapotranspiration rates and associated plant morphological characteristics. Crop Sci. 28:328-331.

Kopec, D. M., R.C. Shearman, and T.P. Riordan. 1988. Evapotranspiration of tall fescue. HortScience 23:300-301.

Rice, J. S., E.M. Glenn, and V.L. Quisenberry. 1979. A rapid method for obtaining leaf impressions in grasses. Agron. J. 71:984-986.

Shearman, R.C. 1986. Kentucky bluegrass cultivar evapotranspiration rates. HortScience 21:455-457.

Shearman, R.C. and J.B. Beard. 1972. Stomatal density and distribution in Agrostis as influenced by species, cultivar, and leaf blade surface and position. Crop Sci. 12:822-823.

Shearman, R.C. and J.B. Beard. 1973. Environmental and cultural preconditioning effects on the water use rate of Agrostis palustris Huds., cultivar Penncross. Crop Sci. 13:424-427.

Van Bavel, C. H. M., R. Lascano, and D.R. Wilson. 1978. Water relations of fritted clay. Soil Sci. Soc. Amer. J. 42:657-659. 